\title{
15. The social inclusion of immigrants in the United Kingdom and Italy: different but converging trajectories?
}

\author{
Rosa Mas Giralt and Antonella Sarlo*
}

\section{INTRODUCTION}

Over the last 25 years, immigration flows in Europe have significantly increased, both from outside the continent and within the European Union (EU). Traditional countries of destination in Northern Europe have been joined by Southern European ones - such as Italy and Spain in receiving growing immigrant populations. More recently the dramatic increase in the number of asylum seekers coming from war zones, although still relatively low compared to other categories, has brought the issue of immigration to the centre of political discussions. Old and new demands for social services coming from immigrant populations are seen to compete with other social needs, in a context of generalised austerity measures, contributing to a radicalisation of political discourses about the social inclusion of immigrants.

Few data suffice to illustrate the changed geography of immigration. According to Eurostat (2016), the number of people born in a non-EU country that were resident in the EU-28 on 1 January 2014 amounted to 33.5 million, with the highest numbers in Germany (7.0 million), the United Kingdom (henceforth UK) (5.0), Italy (4.9), Spain (4.7) and France (4.2). As a percentage of the total resident population, the share of foreign residents was highest in Spain (10.1 per cent), followed by Germany (8.7 per cent), Italy (8.1 per cent) and the UK (7.8 per cent). Although the latter figures reflect different immigration histories and citizenshipgranting regimes, it is unquestionable that the five countries mentioned above now concentrate the large majority of foreign residents, to an extent that is higher than their share of the overall population: 76 per cent of all foreign residents in the EU-28, compared to 63 per cent of total residents (Eurostat, 2016).

The distance between established countries of immigration and 
'latecomers' has also shrunk in relation to immigration policies. As stressed by several scholars (Caponio, 2004; Zincone, 2009; Ambrosini, 2008), the different 'immigration models' identified in Europe in the second half of the last century are now outdated, as the original strategies - assimilationist, multiculturalist, pluralist - have become increasingly muddled and stratified, as a consequence of evolving national preoccupations and aims. Different categories of immigrants are granted different social rights, especially in what concerns access to social services. Moreover, a growing divergence is observed between national regulations and local policies, together with a greater diversification among local practices for the social inclusion of immigrants (Ambrosini, 2008).

Against this general background and in tune with Ambrosini's reading, the key aim of this chapter is to explore to what extent two countries that were initially very different with regard to origin and timing of immigration, management of their integration, and structure of the welfare state, such as the 'pluralist' UK and the 'latecomer' Italy, have come to converge in the last 15 years and reduce their differences in relation to the social inclusion of immigrants and their access to social services. To do so, we will make a distinction between immigration policy - legislation dealing with the 'entry' of immigrants, and immigrant (integration) policy - legislation and programmes dealing with the social inclusion of immigrants, i.e. the granting of social rights and services (Hammar, 1989). In what concerns the latter, we shall distinguish among three main categories of social services, which exhibit different degrees of 'right' (Busso et al., 2013):

- 'Universalistic' social services, such as health or education, the access to which is generally regulated at the national level and depends on the legal status of immigrants. In many countries the regional and/or municipal government levels have substantial discretionary power in applying such regulation in more or less restrictive terms.

- 'Migrant-specific' social services, such as legal aid, counselling, job search or housing assistance, which are specifically targeted at the foreign population, exhibit a weaker national regulation and are generally organised and provided at the regional or local scale.

- 'Ethnic-sensitive' social services, such as language assistance or dedicated counselling, which are targeted at specific ethnic groups to facilitate their access to 'universalistic' services, the regulation and supply of which is highly differentiated among EU countries, as they are generally organised and provided exclusively at the local level.

In what follows we shall first provide some theoretical background to the understanding of welfare, immigration and immigrant policies. 
Subsequently we will summarise the national trajectories and current policy approaches to immigration in the UK and Italy, with particular attention to the access of documented or regular immigrants ${ }^{1}$ to social services. In the last section of the chapter we will draw some conclusions and highlight similarities and differences between the two models.

\section{IMMIGRANTS AND WELFARE: CONCEPTUAL PERSPECTIVES}

Given the relevance that immigration has acquired in welfare debates, a growing comparative social policy scholarship has highlighted the need to develop better understandings of immigrants' social rights and their 'actual' (not only formal) inclusion/exclusion from welfare systems (Sainsbury, 2006, 2012; Wilkinson and Craig, 2011). Depending on their overall attributes, different welfare systems incorporate the social rights of resident non-citizens to a greater or lesser extent, for instance, in relation to base of entitlement (need, work and/or citizenship), type of benefits (flat rate or earnings-related) or type of funding (taxation normally being more inclusive) (Sainsbury, 2012). Different combinations of these attributes mean different levels of inclusivity for newcomers in relation to universalistic policies and social services addressed to the general population.

As Sainsbury (2006; 2012) has suggested, immigrants' social rights in any given country are also mediated by specific immigration and immigrant policies that regulate the conditions whereby newcomers are able to enter and become members of their receiving societies. Immigration policy regulates the range of entry categories in any given country: asylum seekers, economic immigrants according to types of visas, family members, etc. (Sainsbury, 2006). Each of these entry categories is normally granted more or less restrictive entitlements to accessing social benefits - whether cash benefits or in-kind services (Hammar, 1989). These differential entitlements are related to immigrant policy, by regulating the level of access to public services granted to newcomers. A related wider dimension of immigrant policy is the overall 'incorporation or integration' regime, which determines newcomers' possibilities to acquire permanent residency or citizenship (Sainsbury, 2006).

In this chapter, we build on Sainsbury's (2006; 2012) analytical approach to studying the social rights of immigrants by considering the intersection of these policy domains (welfare, immigration and immigrant policies) with the systems of government and governance that manage and implement them. Although commonly understood as concerning federal or multinational states, multilevel systems of government also apply to the 
relations between central, regional and local authorities in unitary states (Hepburn and Zapata-Barrero, 2014). These multilevel systems may also include multilevel policies for a particular social area as is often the case with immigrant incorporation. The governance apparatuses which are responsible for implementing these multilevel policies can be considered 'Type II Multi-level governance' systems (Hooghe and Marks, 2003, p. 237), as they incorporate a significant number of jurisdictions, operate at multiple territorial scales and have task-specific (immigrant integration) and flexible approaches. As has been noted, processes of immigrant integration take place primarily at the local level (Scholten, 2014). It is at this level that immigrants lead their lives in the receiving society, need to enrol their children in school, find jobs and housing, and interact with social and health services. It is also at this level that their social needs become apparent, and intersecting levels of policy and implementation respond or fail to respond to these needs.

As Scholten (2014, p. 151) has highlighted, the recognition that 'migrant integration is a multilevel policy field [. . .] does not mean that policy processes and policy efforts at the various levels are necessarily harmonious and congruent'. Taking into account the multilevel nature of immigrant integration policy, and according to the theoretical and analytical framework that informed the COST Action IS1102 SO.S. COHESION - Social services, welfare states and places and the present book, we propose that to understand fully the social rights of immigrants in a given country, we need to interrogate: (a) the 'vertical' division of authority within the state with regard to immigration and immigrant policies and the tensions between central and regional/local government; (b) the 'horizontal' division of responsibility, that is the enlarged local governance of immigrant policies and services, including a range of non-governmental organisations, more or less supported by the national and local governments; (c) the actual role of such organisations in complementing and/or substituting for public social services. In the next two sections, we analyse the trajectories of the UK and Italy in the last decades in relation to these different dimensions.

\section{IMMIGRATION AND SOCIAL CITIZENSHIP IN THE UNITED KINGDOM}

The UK has a longer history of immigration than many other European nations, and its modern period is normally traced back to the end of the Second World War, when a significant shortage of labour in the country transformed colonies and ex-colonies in main sources of immigrant workers (Spencer, 2011a). For instance, the number of people born in India 
residing in England and Wales nearly doubled between 1961 and 1971 from 157000 to 313000 (Office for National Statistics, 2013). Gradually immigration to the UK has grown and diversified and the UK-born minority ethnic population has increased. Census data highlights that in 2011, 20 per cent of the population identified with an ethnic group other than White British in contrast to 3 per cent in 2001 (Jivraj, 2012). Since the early 2000s, the heterogeneity in country of origin has been accompanied by other types of immigration and diversification along the lines of gender, age, religion, language, migration channel and status; a situation which Vertovec (2007) has conceptualised as 'super-diversity' and which has significant consequences for the range of social needs of immigrants.

Since the 1950s, immigration policy in the UK has followed an increasingly 'restrictive' trajectory, although also responding to economic requirements for labour and to public pressures in different periods (Spencer, 2011a). For instance, the economic prosperity of the late 1990s and early 2000s led successive Labour governments (1997-2010) to shift to policies committed to economic immigration but with stricter security controls ('secure borders' after the 9/11 and 7/7 terrorist attacks). In addition, British authorities have increasingly adopted measures of 'exclusion from the welfare state' as tools of immigration control (Spencer, 2011a, p.45). As entitlement to most public services and benefits in the UK is determined by 'residence and need', this has long raised concerns that immigrants would 'take advantage' of the welfare and health systems (The Migration Observatory, 2014). Consequently, successive UK governments have introduced welfare restrictions and/or 'tests of eligibility' to delay 'immediate' social rights for immigrants (Spencer, 2011a). Irregular migrants have actually been stripped of nearly all social rights and can only access compulsory education and emergency healthcare.

For regular migrants, a main restrictive mechanism has been the application of the principle of 'no recourse to public funds' (introduced by the Immigration Act 1971) to an increasing number of immigrants from third countries, non-EU/EEA ${ }^{2}$ (Wilkinson and Craig, 2011; Sainsbury, 2012). Since the 1980s, an expanding range of benefits, tax credits and allowances have been classified as 'public funds' (social housing, means-tested jobseeker's allowance and so on), thus effectively excluding newcomers from these provisions (Sainsbury, 2012). Immigrant policies related to naturalisation have also become stricter, as the residence period for 'new' immigrants to qualify for settlement status and thus rights of access to 'public funds' has been gradually extended and normally requires five years' legal residence (Sainsbury, 2012).

Following the 2004 and $2007 \mathrm{EU}$ enlargements, the increase of EU/ EEA immigration to the UK has come to dominate governmental and 
public attention, renewing populist discourses of 'benefit and health tourism' in the country. Despite little evidence that the welfare system works as an attraction for EU/EEA migrants - fewer than 5 per cent were claiming jobseeker's allowance in 2013 (The Migration Observatory, 2014) - consecutive British governments have introduced measures to restrict (mainly delay) EU/EEA immigrants' access to welfare assistance (Kennedy, 2015). Effectively the 'no recourse to public funds' and eligibility tests have created a mosaic of differentiated social rights for newcomers in the UK, which, together with a shortage of funding and resources at the local level, are making delivery of social services for immigrants increasingly difficult.

\section{The Vertical Division of Authority Within the State: The Shift of Social Inclusion Responsibilities from the National to Lower Levels of Government}

In the UK responsibility for immigration policy and related regulations regarding welfare entitlements for different types of immigrants has remained the prerogative of the central government. However, this has not been accompanied by the development of a national policy framework on immigrant integration (Spencer, 2011b). Instead, from the 1960s, the UK's integration approach has generally had a mainstreaming character; that is, by making 'an effort to reach people with a migration background through needs-based social programming and policies that also target the general population' (Ali and Gidley, 2014, p. 1). Examples of this approach are found in the significant anti-discrimination legislation which has been passed since the 1970s or the 'community cohesion' policies first introduced in the 2000s in response to the 'segregation fears' prevalent after the 9/11 and 7/7 terrorist attacks.

In the year 2000, the UK saw the deployment of its only formal national immigrant integration policy, which made exclusive reference to refugees; this policy, expanded in 2005, set out a clear framework to manage the integration process of refugees across the country (Home Office, 2005). During the third term of the Labour government (2005-10), responsibility for immigrant integration (except for refugees) was transferred from the Home Office (national level) to the Department of Communities and Local Government. The Conservative-Liberal Democrat or Coalition Government (2010-15) embraced a 'community cohesion' approach (through its policy paper 'Creating the conditions for integration') based on shared values, social responsibility, active participation, social mobility and rejection of extremism, thus not 'targeting' immigrants exclusively, but communities as a whole (Ali and Gidley, 2014). 
In the devolved and multi-tiered government system of the UK, integration approaches have varied across England, Scotland, Wales and Northern Ireland, and within them. In this system, a range of areas of service provision are devolved to local authorities (education, housing), who have considerable freedom to develop their own goals in integration policy and related migrant-specific or ethnic-sensitive services (Ali and Gidley, 2014). For instance, in 2009 the Mayor of London implemented an integration strategy for refugees and migrants in the city (updated in 2013), establishing key priorities such as increasing access to English courses for speakers of other languages and tackling housing, employment, education and health inequalities (Greater London Authority, 2013). However, not all local authorities have developed such strategies and there have been different levels of engagement with the integration of immigrants across the country (Ali and Gidley, 2014).

In the UK, the local provision of social and health services involves a range of public and sub-contracted actors. Some services and provisions are the responsibility of the local authority (education, housing, social care, council tax benefit), but in-/out-of-work benefits are managed nationally by the Department of Work and Pensions through local delivery offices (Department for Work and Pensions, 2016). In addition, primary healthcare is provided through practices of general practitioners or dentists for local catchment areas who are contracted by the National Health Service (National Health Service, 2013). Overall, the complex system of immigrant categories and differentiated social rights makes it difficult for front line staff in this range of 'local' services to establish immigrants' entitlements, which may lead to discrimination when access is refused (CAP Mas Giralt, 2014). In some instances, welfare restrictions also prevent local authorities from assisting vulnerable immigrants (with 'no recourse' to public funds) and may jeopardise public services' duty of care towards victims of trafficking and exploitation.

There is an additional constraint to local authorities' ability to develop or fund 'migrant-specific' or 'ethnic-sensitive' social services in support of immigrants' integration in their localities. Alongside its transfer of responsibility to the local level, the Coalition Government (2010-15) implemented a political programme intended to reduce the country's fiscal debt and scale down public expenditure. Financial cuts were applied across government and local authorities; for instance, from 2011 and over a five-year period, there were plans to reduce 43 per cent of funding from central government to local authorities (Local Government Association, 2013). The measures implemented have also affected the taxes that local authorities can collect, including a cap on Council Tax (the most substantial local tax). Thus, financial constraints further jeopardise the activities of local authorities 
and, in the last few years, services or initiatives addressing the social needs of immigrants have been curtailed. A recent study, conducted with Latin American immigrants (with EU citizenship) in London, identified that since 2010 cuts in public funding have translated into a retrenchment of 'ethnic-sensitive' social services (outreach and interpreting services) provided by local authorities for newly arrived immigrants, in turn leading to difficulties in accessing 'universalistic' services (CAP Mas Giralt, 2014).

\section{The Horizontal Division of Responsibility: The Relevant Role of Third-Sector Organisations}

The multi-tiered governance systems of the UK are characterised by a strong reliance on cross-sectoral partnerships, which incorporate nonstatutory actors and coordinate different statutory agencies. In the early 2000s, the Home Office funded 12 regional 'Strategic partnerships for asylum and refugee support' across the UK, which in 2007 widened their remit to incorporate all types of immigrants (Ali and Gidley, 2014). The subsequent shift of the Coalition Government (2010-15) towards localism stripped many of these partnerships of their 'regional' identity (and some ceased to exist), but many continue to play a significant role in coordinating integration initiatives in their regions.

These partnerships are funded by the central government and include representatives from local authorities and a range of statutory agencies (health, police and education services), migrant and refugee organisations and the Home Office; they may also include representation from the private sector (Ali and Gidley, 2014). They fulfil a strategic role by facilitating collaboration among public, non-governmental and private actors; monitoring trends to inform policy and minimise adverse local impacts; working with local delivery partners to design and oversee services that respond to immigrants' needs; and acting as a point of contact between the Home Office, other government departments and regional partners (Migration Yorkshire, 2015).

However, in recent years, local statutory and non-statutory actors have faced increasing difficulties to access state funds to address the local impacts of immigration. For instance, the Labour government introduced a GBP 50 million Migration impact fund (MIF) in 2009, financed through a GBP 50 levy on the visas of non-EU/EEA immigrants entering the UK (Tonkiss, 2013). The MIF sought to support the local integration of immigrants and assist with the costs of the transitional impacts of immigration on public services. Applications to the funds were open to councils, police, health trusts and third-sector organisations. In 2010, however, the Coalition Government axed the fund, alleging that 'the impacts of migra- 
tion [were] better addressed though controlling immigration' (Tonkiss, 2013). Without funding streams such as MIF, local authorities have struggled to cope with increases on service demand.

\section{Third Organisations at the Local Level: Agents of Change or Substitute Providers?}

As the previous section implies, third-sector actors play an important role in supporting the integration of immigrants in the UK. Although this sector involves all types of voluntary, community and charity organisations with a remit in social inclusion and welfare, it also includes distinctive minority ethnic and immigrant groups (Black and minority ethnic voluntary and community sector - BMEVCS). Starting in the 1960s to 1980s, a range of grassroots initiatives were developed, including self-help strategies such as educational activities, co-ethnic financial assistance or savings committees in the South Asian and Caribbean communities, or even more formal forms of organisation such as the black housing movement created to address the discrimination that BME residents faced in mainstream housing (Craig, 2011). Thus, a semi-formal BMEVCS began to emerge in the 1980s and was consolidated and diversified in the 1990s, reflecting a tradition of pluralist approaches at the local level (Craig, 2011). Many of their activities were initially funded through community resources but as associations established themselves more formally, state support became available if they provided specialised services to minority groups ('migrant-specific' or 'ethnic-sensitive' social services). For instance, some BME groups have been entrusted by mainstream welfare services to deliver specialist provision, such as care for older people (Craig, 2011). These organisations have also played prominent roles in advocating and lobbying for the social rights of immigrants (Craig, 2011; Ware, 2013).

However, during the last few years, this sector's resources have been depleted by the loss of financial support from central and local government and the difficult fundraising and economic climate post-2008 (Ware, 2013). Thus, the horizontal subsidiarity that had long characterised the delivery of 'migrant-specific' and 'ethnic-sensitive' social services for immigrants and minority ethnic residents in Britain has been increasingly disrupted (Craig, 2011). At the same time, within the transition from diverse to super-diverse immigrant populations, third-sector organisations have experienced a significant increase in the demand for advisory and support services due to a shortage of appropriate statutory provision (Craig, 2011; CAP Mas Giralt, 2014).

The Coalition Government (2010-15) and current Conservative Government (2015 onwards) and their agenda of 'devolution' to 'the 
local level' has had a significant impact on the type of expectations placed on third-sector actors in the delivery of social services. The Coalition Government introduced the so-called 'Big society' ideology based on the premise of 'reduc[ing] the state's role and empower[ing] [ . . . civil society to deliver services' (Ali and Gidley, 2014, p. 8). Although not formally adopted in legislation (and subsequently abandoned), the philosophy of the 'Big society' is implicit in the Localism Act 2011 and its view of voluntary and community groups as conducting 'the most innovative and effective work in public services' and the benefits of involving these groups and individuals further in 'tackl[ing] problems in the way they want' (Department for Communities and Local Government, 2011, p. 8). Despite this, in February 2016, the Conservative Government announced that it would insert a new clause into all its grant agreements to prevent such funds being used by charities and other voluntary organisations to lobby government (Ricketts, 2016). The National Council for Voluntary Organisations has highlighted that this move is 'tantamount to making charities take a vow of silence' and it potentially disrupts the historic role of this sector in promoting policy change and social inclusion (Ricketts, 2016).

\section{IMMIGRATION AND SOCIAL CITIZENSHIP IN ITALY}

Italy is generally included in the so-called 'Southern European immigration model' (Pugliese, 2002). Some scholars actually consider it a 'paradigmatic case' (King and Ribas-Mateos, 2002), characterised by a late and rapid increase of immigration flows - mostly generated on the supply side and informally inserted into the local labour markets - and by a late and reluctant acknowledgement and regulation by public actors (Pugliese, 2002).

According to Mantovan (2007), the specific features of what she calls the 'implicit' Italian integration model include: (a) a weak national regulatory framework, as witnessed by the repeated use of amnesties and ad hoc decrees to regularise immigrants and deal with emergency issues; (b) the limited action of central government institutions and, in contrast, the relevant role of regional and local actors - both public and private - in addressing the economic and social inclusion of immigrants; (c) the initially informal and casual forms of insertion in the labour market and the local socioeconomic context, only subsequently and progressively institutionalised; and (d) the predominance of employment in manual and unskilled tasks, often with no regular contract (especially in the South). Two more specific traits can be added: (e) the great heterogeneity of origin, which stems from the absence of a strong colonial past; and (f) the 
great regional differentiation in socioeconomic structures and immigrant inclusion practices (Ambrosini, 2005; Balbo, 2015). The latter features make Italy eligible for the concept of 'super-diversity' originally coined by Vertovec (2007) to describe the UK immigration model, underscoring the possible convergence between Southern and Northern European immigration models.

Recent trends have further complicated the picture. The financial crisis of 2008 and the ensuing industrial closures in Northern Italy have triggered a territorial diffusion of immigrants, as employment has shifted from industry to agriculture and from Northern to Southern regions, where opportunities to find casual work in agriculture are greater (Pugliese, 2013; Sarlo, 2015). Settlement preferences have also shifted from large metropolitan areas to small municipalities and rural places, in search of cheaper housing (Balbo, 2015; Sarlo et al., 2014). At the same time, the political crises and the new conflicts arising in the Southern and Eastern shores of the Mediterranean have generated new daily humanitarian emergencies.

In this evolving context Italian immigration policies, which have remained a prerogative of the central state, have been swinging - in a sort of 'bipolar' mode - between 'opening' and 'closing' stances (Sarlo et al., 2014), a fact that aggravated the unclear division of labour between different levels of the state and the possibility to implement a coherent strategy. At the same time, immigrant policies, which were already characterised by inadequate regulation, have witnessed a progressive pulling out of the central state and a shift of responsibility onto local governments. Local welfare systems are thus forced to address added demands for services, which magnify already existing structural inadequacies (Zincone, 2009). In this context, the relevant role played by the EU, through its Cohesion policy, in the implementation of local immigrant policies and practices must be stressed. In fact, many local projects for the social inclusion of immigrants throughout Italy were financed with resources from the European structural funds.

\section{The Vertical Division of Authority Within the State: The Shift of Social Inclusion Policies from the Central State to Regional and Local Governments}

In the last fifteen years, there has been a paradigmatic change in national immigration policies in Italy: from an approach based on the 'certainty of social security rights' to an approach based on the 'right to security' (Baratta, 2000), which, while attempting to control immigration flows, also tended indirectly to undermine immigrants' social rights. Three legislative acts mark this evolution.

The National law 40/1998 (aka 'Turco-Napolitano law', later transformed 
into the Legislative decree 286/1998) was approved by a centre-left government and marked the transition from a piecemeal approach to a more coherent regulatory framework. For the first time the notion of immigrant policy was introduced and a 'reasonable integration model' was posited (Zincone, 2000), which established a clear distinction between 'regular' and 'irregular' immigrants. The former were granted social rights and access to 'universalistic' social services such as public health care, social security benefits, social housing; the latter were only granted access to compulsory public education and emergency health services. The law established a dedicated National fund for immigrant policies (Fondo nazionale per le politiche migratorie), i.e. for the implementation of plans for the social inclusion of immigrants, a Committee for integration policies (Commissione per le politiche di integrazione) and a Council for immigration (Consulta per l'immigrazione), made up of representatives from the regional governments, municipalities and civil society organisations. It also defined the vertical division of responsibility among the different levels of the state: while immigration policies (entry procedures and quotas) remained firmly with the central state, the responsibility for immigrant policies was transferred to regional governments and municipalities, albeit still within a national regulatory and funding framework (Caponio, 2004) - thereby anticipating the Constitutional reform of 2001, which would transfer to regional governments the exclusive responsibility on all social services.

The subsequent National law 189/2002 (aka 'Bossi-Fini law'), approved by a centre-right government, did not alter the general structure of the previous legislation, but introduced more rigid requirements for entry and permanence. More importantly, although ostensibly maintaining the 'reasonable integration' approach, the central government initiated an indirect strategy of disengagement from immigrant policy, by progressively dismantling both the funds and the committees established to support the early multiscalar approach to immigrant policies, thereby transferring onto regional and local governments the financial burden of supporting the social inclusion of immigrants.

With the National Law 94/2009 (aka 'Maroni law' or 'Security package'), also approved by a centre-right government, the 'reasonable integration' strategy was explicitly abandoned and a straightforward 'security-oriented' approach was adopted. The new law made it very difficult for immigrants to maintain a 'regular' status, by 'designing the legal position of foreigners as guests, on perpetual trial, for whom the test never ends' (Bascherini, 2010 , p. 462, translated from Italian). Indirectly, the new legislation also made access to social rights more difficult, further undermining the initial fragile attempt at establishing an inclusive policy framework. Moreover, it granted greater power to mayors and municipal councils in the domain 
of public order and security, thereby opening the possibility for veritable 'exclusionary' actions at the local level, via municipal decrees and warrants allegedly pursuing public order (Ambrosini and Caneva, 2012).

The existence of national, regional or local regulation in Italy does not necessarily mean that they are consistently applied. The increased discretionary power given to local authorities to interpret and mediate between, on the one hand, the national policies oriented to 'control', and, on the other hand, the necessity to address the needs of immigrants locally, has contributed to amplify the distance between discourses, legislation and practices, and the already existing territorial differentiation in the way Italian regions and localities deal with the social inclusion of immigrants (Ambrosini and Caneva, 2012; Balbo, 2015). These contradictions and differences are particularly evident in relation to, for example, the granting of 'legal' residence, which is the key step for accessing 'universalistic' social rights; or the application of means-tested fees in certain social services such as daycare. Strange paradoxes can be found between formal entitlements and 'actual' access to services. For instance, in some North-Eastern regions and municipalities governed by centre-right coalitions - where political discourses are outright exclusionary and where municipal decrees allegedly oriented to maintain 'public order' have been enacted which limit the access of immigrants to certain public facilities - immigrants actually do enjoy access to most social services (Cancellieri et al., 2014; Semprebon, 2014). In contrast, in some Southern regions, where inclusive discourses are showcased and dedicated policies are promoted (see, for example, the Appulia Regional Plan for Immigrants 2013-15), dramatic situations of social exclusion and exploitation of seasonal immigrant workers in agriculture are still found (Galossi, 2011).

\section{The Horizontal Division of Responsibility: The Relevant Role of Third-Sector Organisations}

The local is thus the key government level in Italy to deal with the needs of the varying and increasingly complex social universe of immigrants. As early as the late 1980s, in the absence of any specific regulatory framework, forms of 'horizontal subsidiarity' had developed. With the more recent retrenchment of the national government in what concerns both immigrant policy and social services in general, local collective actors - often of quite diverse origin, ranging from business associations to trade unions, from Catholic organisations to lay voluntary groups, from philanthropic foundations to community organisations - have become invaluable providers of social services to immigrants (Ambrosini, 2005; Barberis, 2009), complementing or even substituting for local authorities. 
These 'organised solidarity' actors (Ambrosini, 2005) - associated in varying networking configurations, local and national - provide both 'migrant-specific' services such as legal aid, orientation services, housing or job application procedures and 'ethnic sensitive' services such as language classes or cultural mediation. They also perform a key role in building awareness and information about the immigration phenomenon (Ambrosini, 2005), and a lobbying and advocacy role, at both central and local levels (Zincone and Di Gregorio, 2002). For example, business associations have at times put pressure on the central government for less restrictive entry policies, while advocating more inclusive social policies at the local level (Barberis, 2009, p. 236); trade unions have played a key role in advocating for better integration policies and access to social services; and Catholic organisations have played a double role as service providers and pressure groups for more inclusive immigrant policies (Barberis, 2009).

The recent territorial diffusion of immigrants and the intensifying landings of asylum seekers, especially in the South, have further triggered local 'organised solidarity' initiatives, in which 'short-range' community networks interact with 'long-range' solidarity networks such as Caritas, Médecins sans Frontières or national trade union organisations, generating answers to the social needs of immigrants, in different forms and with different degrees of institutionalisation - also depending on the local social capital, welfare system and political traditions. As stressed by Barberis (2010, p. 47, translated from Italian), a 'micro-regulation model, without a central state paradigm and largely based on residualism and local networks' has thus taken shape in Italy.

\section{Bottom-up Initiatives at the Local Level: Agents of Change or Substitute Providers?}

In Italy, many bottom-up local initiatives have developed in relation to pressures created by immigration since the very beginning of the phenomenon. It is actually possible to identify a 'thread' running across different initiatives, in different urban contexts, with different origins and aims, through three main phases.

The first phase started in the late 1980s and was characterised by the absolute centrality of local authorities, in the absence of any national regulatory framework. Initiatives mostly concerned the social inclusion of 'economic' migrants in the large cities of the North and influenced the national legislation to a significant extent (Caponio, 2004). In Milan, for example, a Municipal council for immigration (Consulta cittadina per l'immigrazione) was created in 1986, a Centre for foreigners (Centro per gli stranieri) was opened in 1989, and literacy classes for adults and initiatives to help chil- 
dren settle at school were launched (Zincone, 2009). Similar educational, hospitality and mediating services to facilitate access to social services as well as formal immigrant organisations were created in Turin and Bologna in the late 1980s and early 1990s (Caponio, 2004).

The second phase started in the late 1990s and was more emergencydriven, prompted by the recurring arrival of immigrants from war zones, especially in the South. Particularly interesting in this phase were the initiatives that unfolded from 1997 in a few small municipalities of Calabria (Badolato and Riace), which linked the humanitarian reception of asylum seekers with an urban regeneration strategy, through projects that mobilised the immigrants themselves in rehabilitating the abandoned housing stock in old depopulated boroughs (Sarlo, 2015; CAP Sarlo and Martinelli, 2016). This practice was later institutionalised with a dedicated regional law and even influenced the national 'Bossi-Fini law', which established the Protection system for asylum seekers and refugees (Sistema protezione richiedenti asilo e rifugiati - SPRAR).

The third phase was triggered by the onset of the economic crisis in 2008 and the 'Maroni law' of 2009, with the ensuing cuts in national funding and the curtailment of immigrants' social rights. It is characterised by a further proliferation of local practices, answering a variety of local needs, sometimes - again - with truly innovative features: from those deployed in Lombardy, such as the housing and service activities developed with and for immigrants in the small municipality of Breno or the participatory processes developed in the province of Brescia to promote a vision of integration as a common good (Semprebon, 2014), to those experimented within Latium, such as the XI Comunità Montana 'Castelli romani e prenestini', which promoted initiatives to support the employment of immigrants in the hotel and tourism sector (Cremaschi and Fioretti, 2015).

What brings together this quite variegated range of initiatives is that they basically act as surrogates for a missing national policy, supporting Barberis' notion of an Italian 'micro-regulation model' (2010). This fact in turn raises two relevant questions. First, are immigrants in the end the most expendable among vulnerable social groups and hence the target of a more or less explicit disengagement of the central state from providing social inclusion services? Second, how far can local innovative initiatives go if their role is no longer to challenge - and contribute to change - the way social services are provided, but only to substitute for them in the context of an increasingly exclusionary national agenda? Bottom-up practices cannot be expected to 'work miracles' (Mingione and Vicari, 2015, p. 100, translated from Italian). They are not sustainable 'in the absence of a stable policy and normative framework and, most importantly, of a defined social project' (Barberis, 2010, p.47, translated from Italian), as 
well as in the absence of stable funding mechanisms (Martinelli, 2012). Moreover, precisely because of the lack of national regulation and funding and their dependence on bottom-up local initiatives, the social rights of immigrants are widely uneven among places, a fact that mirrors the Italian territorial differentiation in the supply of social services in general, but is certainly aggravated in the case of services for immigrants.

\section{CONCLUDING REMARKS}

This chapter sought to contribute to understanding immigrants' social rights and their inclusion/exclusion from social service provisions in the UK and Italy. To conclude this endeavour, we reflect on the similarities and differences observed in our analysis of the two countries' trajectories, in relation to the 'vertical' and 'horizontal' divisions of responsibility for immigration/immigrant policies and services and to the role of nongovernmental organisations in complementing or substituting retrenching public provisions.

In terms of the 'vertical' division of authority, our review shows that, despite different histories and timings of immigration, the central state in both countries is pulling out of immigrant 'integration' policy and concerning itself prevailingly with immigration policy, while explicitly or implicitly curtailing newcomers' social rights. In both cases, the responsibility for immigrant policy, particularly in relation to developing migrant-specific and ethnic-sensitive social services, has been shifted to local governments, but with increasingly limited financial resources and support. Tensions between state-led welfare regulations and the needs of immigrants, which are manifest at the local level, expose contradictions. In the UK, a growing diversity of immigrant categories with differential social rights regulated by central government may translate into further exclusion in practice when difficulties in establishing immigrants' entitlement lead to barred access to local services. In Italy, particular local manifestations of the crossing between national immigration policies and local integration initiatives result in inconsistent levels of access to services in different localities. Despite synergies, there are still significant differences in the overall approach to vertical coordination across different government levels in both cases. Although eroded during the Coalition (2010-15) and Conservative (current) administrations, cross-sectoral regional migration partnerships in the UK play a key role in acting as a 'point of contact' between lower levels of government and the Home Office. In contrast, Italy shows a greater level of 'formal' disconnection between different levels of government. 
There are also significant parallels between the two countries in terms of their 'horizontal' division of responsibility at the regional/local levels. In both cases, 'horizontal subsidiarity' has developed, involving a wide range of local actors who provide both 'migrant-specific' and 'ethnic-sensitive' services and often lobby for the social rights of immigrants. Differences remain in the formal recognition of cross-sectoral partnerships. In Italy, these types of partnerships seem to have been developed through particular bottom-up initiatives in particular localities and regions, while the UK has a long history of cross-sectoral collaborations across all types of social services. Nonetheless, the 'withdrawal' of the British central government in providing 'leadership' in the immigrant integration policy area and its curtailment of funding streams both at national and local levels has deeply disrupted the traditional horizontal subsidiarity which had characterised the delivery of services for immigrants.

In both countries, third-sector and other solidarity actors are thus 'compensating' for retrenching or nonexistent public provision at local level, especially in relation to 'migrant-specific' and 'ethnic-sensitive' social services. ${ }^{3}$ In the UK, both the former Coalition and the current Conservative governments have explicitly recognised the key role thirdsector actors can play in the delivery of 'locally appropriate' social services, but without proper resourcing this sector cannot perform the tasks entrusted to them and cannot respond to the growing and diversifying needs of immigrants. In Italy, the recognition of third-sector organisations is less explicit and, in the absence of stable normative frameworks or funding mechanisms, services for the social inclusion of immigrants increasingly depend on bottom-up local solidarity initiatives which have no means to transform into sustainable solutions. In both countries, the augmented role of the local level and the varied nature of micro-approaches are contributing to a growing territorial differentiation in the provision of services for the social inclusion of immigrants.

\section{NOTES}

* This chapter is the joint product of a close collaboration between the two authors. However, the Introduction and section 3 should be attributed to Antonella Sarlo and sections 1 and 2 to Rosa Mas Giralt, whereas the Conclusions are obviously shared.

1. Undocumented or irregular immigrants in both countries have limited social rights - i.e. access only to basic compulsory education and emergency healthcare.

2. Non-European Union/European Economic Area immigrants.

3. In the case of undocumented or irregular immigrants, these organisations play a key role in filling a structural gap, by providing services to people who would otherwise be completely excluded from social services. 


\section{REFERENCES}

Ali, S. and B. Gidley (2014), Advancing Outcomes for All Minorities: Experiences of Mainstreaming Immigrant Integration Policy in the United Kingdom, Brussels: Migration Policy Institute Europe.

Ambrosini, M. (2005), Sociologia delle migrazioni, Bologna: Il Mulino.

Ambrosini, M. (2008), Un'altra globalizzazione. La sfida delle migrazioni transnazionali, Bologna: Il Mulino.

Ambrosini, M. and E. Caneva (2012), Local Policies of Exclusion: the Italian Case, Technical Report ACCEPT-PLURALISM; 2012/07, 4, Seventh EU Framework Programme, European University Institute, accessed 12 June 2016 at http://cad mus.eui.eu/handle/1814/22317.

Balbo, M. (ed.) (2015), Migrazioni e piccoli comuni, Milan: F. Angeli.

Baratta, A. (2000), 'Diritto alla sicurezza o sicurezza dei diritti?', Democrazia e Diritto, no. 2, 19-36.

Barberis, E. (2009), 'La dimensione territoriale delle politiche per gli immigrati', in Y. Kazepov (ed.), La dimensione territoriale delle politiche sociali, Roma: Carocci, pp. 223-46.

Barberis, E. (2010), 'Il ruolo degli operatori sociali dell'immigrazione nel welfare locale', La Rivista delle Politiche Sociali, XXIV (1), 45-60.

Bascherini, G. (2010), 'Immigrazione e nuovi paradigmi della sicurezza. Note sulla penalizzazione delle irregolarità migratorie', in S. Gambino and G. D'Ignazio (eds), Immigrazione e diritti fondamentali, Milan: Giuffrè Editore, pp. 461-80.

Busso, S., E. Gargiulo and M. Mannocchi (2013), Multiwelfare. Le trasformazioni dei welfare territoriali nella società dell'immigrazione, Turin: FIERI Rapporti di Ricerca, accessed 12 June 2016 at http://fieri.it/wp-content/uploads/2013/09/ RAPPORTO-Multiwelfare_SETTEMBRE-2013.pdf.

Cancellieri, A., G. Marconi and S. Tonin (2014), Migrazioni, politiche e territorio in Veneto, Venice: Cattedra Unesco SSIIM, Università Iuav di Venezia, accessed 12 June 2016 at http://www.unescochair-iuav.it/blog/rapporti-di-ricerca/.

Caponio, T. (2004), 'Governo locale e immigrazione in Italia. Tra servizi di welfare e politiche di sviluppo', Le istituzioni del federalismo, 25 (5), 789-812.

Craig, G. (2011), 'Forward to the past: can the UK black and minority ethnic third sector survive?', Voluntary Sector Review, 2 (3), 367-89.

Cremaschi, M. and C. Fioretti (2015), 'Il Lazio e l'area metropolitana', in Balbo M. (ed.), Migrazioni e piccoli comuni, Milan: F. Angeli.

Department for Communities and Local Government (2011), A Plain English Guide to the Localism Act, London: Department for Communities and Local Government.

Department for Work and Pensions (2016), About Us, London: Gov.uk, accessed 12 June 2016 at https://www.gov.uk/government/organisations/depart ment-for-work-pensions/about.

Eurostat (2016), Migration and Migrant Population Statistics, Brussels: European Commission, accessed 21 April 2016 at http://ec.europa.eu/eurostat/statisticsexplained/index.php?title=Migration_and_migrant_population_statistics\&old id $=228736$.

Galossi, E. (ed.) (2011) Immigrazione, sfruttamento e conflitto sociale. Una mappatura delle aree a rischio e quattro studi di caso territoriali, Research Report, 
Rome: IRES-Istituto di Ricerche Economiche e Sociali, accessed 15 June 2016 at users2.unimi.it/escapes/wp-content/uploads/Indagine_territori_a_rischio.pdf.

Greater London Authority (2013), London Enriched: Update, London: Greater London Authority, accessed 12 June 2016 at https://www.london.gov.uk/sites/ default/files/london_enriched_update.pdf.

Hammar, T. (1989), 'State, nation and dual citizenship', in W.R. Brubaker (ed.), Immigration and The Politics of Citizenship in Europe and North America, Lanham: University Press of America.

Hepburn, E. and R. Zapata-Barrero (eds) (2014), The Politics of Migration in Multilevel States: Governance and Political Parties, Basingstoke, UK and New York, USA: Palgrave Macmillan.

Home Office (2005), Integration Matters: A National Refugee Strategy, London: Home Office.

Hooghe, L. and G. Marks (2003), 'Unraveling the central state, but how? Types of multi-level governance', The American Political Science Review, 97 (2), 233-43.

Jivraj, S. (2012), 'How has ethnic diversity grown 1991-2001-2011?', Dynamics of Diversity: Evidence from the 2011 Census Series, Manchester: Centre on Dynamics of Ethnicity (CoDE), University of Manchester, accessed 12 June 2016 at www.ethnicity.ac.uk/medialibrary/briefings/dynamicsofdiversity/howhas-ethnic-diversity-grown-1991-2001-2011.pdf.

Kennedy, S. (2015), 'Measures to limit migrants' access to benefits', Briefing Paper, 06889, London: House of Commons Library, accessed 21 February 2016 at http://researchbriefings.files.parliament.uk/documents/SN06889/SN06889.pdf.

King, R. and N. Ribas-Mateos (2002), 'Towards a diversity of migratory types and contexts in Southern Europe', Studi Emigrazione/International Journal of Migration Studies, XXXIX (145), 5-25.

Local Government Association (2013), 'No more cuts councils tell Chancellor ahead of Autumn statement - LGA press release 5 November 2013', Local Government Association, accessed 12 April 2014 at http://www.local.gov.uk/ media-releases/-/journal_content/56/10180/5636691/NEWS.

Mantovan, C. (2007), Immigrazione e cittadinanza. Auto-organizzazione e partecipazione dei migranti in Italia, Milan: F. Angeli.

Martinelli, F. (2012), 'Social innovation or social exclusion? Innovating social services in the context of a retrenching welfare state', in H.-W. Franz, J. Hochgerner and J. Howaldt (eds), Challenge Social Innovation. Potentials for Business, Social Entrepreneurship, Welfare and Civil Society, Berlin: Springer, pp. 169-80.

Mas Giralt, R. (2014), 'Access to social protection for Latin American migrants with EU citizenship and their families in London: the exclusionary dynamics of migration and welfare policy change in the UK post-2008', unpublished paper presented at the COST Action IS1102 Workshop, University of Tampere, Tampere, 2-6 June.

Migration Yorkshire (2015), 'Strategic Migration Group [SMG]', Leeds: Migration Yorkshire, accessed 14 April 2016 at http://www.migrationyorkshire.org.uk/?pag $\mathrm{e}=$ strategicmigrationgroup.

Mingione, T. and S. Vicari (2015), 'Politiche urbane e innovazione sociale', in A. Calafati (ed.), Città tra sviluppo e declino: un'agenda urbana per l'Italia, Rome: Donzelli, pp. 97-108.

National Health Service (2013), 'The NHS structure explained', NHS Choices, accessed 12 April 2014 at http://www.nhs.uk/NHSEngland/thenhs/about/Pages/ nhsstructure.aspx. 
Office for National Statistics (2013), 'Immigration patterns of non-UK born populations in England and Wales in 2011', London: Office for National Statistics, accessed 11 October 2015 at www.ons.gov.uk.

Pugliese, E. (2002), L'Italia tra migrazioni internazionali e migrazioni interne, Bologna: Il Mulino.

Pugliese, E. (ed.) (2013), Immigrazione e diritti violati. I lavoratori immigrati nell'agricoltura del mezzogiorno, Rome: Ediesse.

Ricketts, A. (2016), 'Government to introduce new clause preventing the use of grant funding for lobbying', Third Sector, accessed 8 April 2016 at http://www.thirdsector. co.uk/government-introduce-new-clause-preventing-use-grant-funding-lobbying/ policy-and-politics/article/1382553.

Sainsbury, D. (2006), 'Immigrants' social rights in comparative perspective: welfare regimes, forms in immigration and immigration policy regimes', Journal of European Social Policy, 16 (3), 229-44.

Sainsbury, D. (2012), Welfare States and Immigrant Rights: The Politics of Inclusion and Exclusion, Oxford: Oxford University Press.

Sarlo, A. (2015), 'L'immigrazione nella Calabria dall'economia fragile', in M. Balbo (ed.), Migrazioni e piccoli comuni, Milan: F. Angeli.

Sarlo, A. and F. Martinelli (2016), 'Housing and the social inclusion of immigrants in Calabria. The case of Riace and the "Dorsal of hospitality", COST Action IS1102 Working Papers, no. 13, accessed 12 June 2016 at http://www. cost-is1102-cohesion.unirc.it/docs/working-papers/wg2.italy-calabria-housingand-social-inclusion-immigrants-sarlo-and-martinelli.pdf.

Sarlo, A., F. Martinelli and M. Imperio (2014), Immigrazione e politiche di inclusione in Calabria, Venice: Cattedra Unesco SSIIM - Università Iuav di Venezia, accessed 12 June 2016 at http://www.unescochair-iuav.it/blog/rapporti-di-ricerca/.

Scholten, P. (2014), 'The multilevel dynamics of migrant integration policies in unitary states: the Netherlands and the United Kingdom', in E. Hepburn and R. Zapata-Barrero (eds), The Politics of Migration in Multilevel States: Governance and Political Parties, Basingstoke, UK and New York, USA: Palgrave Macmillan, pp. 150-74.

Semprebon, M. (2014), Le politiche di inclusione degli immigrati in Lombardia: tra discorsi escludenti, ordinanze securitarie e sperimentazioni innovative, Venice: Cattedra Unesco SSIIM - Università Iuav di Venezia, accessed 12 June 2016 at http://www.unescochair-iuav.it/blog/rapporti-di-ricerca/.

Spencer, S. (2011a), The Migration Debate, Bristol: Policy Press.

Spencer, S. (2011b), Policy Primer: Integration, Oxford: Centre on Migration, Policy and Society.

The Migration Observatory (2014), 'Commentary. Costs and "benefits": benefits tourism, what does it mean?', Oxford: COMPAS, accessed 12 May 2014 at http:// www.migrationobservatory.ox.ac.uk/commentary/costs-and- $\% \mathrm{E} 2 \% 80 \% 98$ bene fits $\% \mathrm{E} 2 \% 80 \% 99$-benefits-tourism-what-does-it-mean.

Tonkiss, K. (2013), 'Migration and integration are now policy challenges too far for many local authorities', Migrants' Rights Network, Migration Pulse blog, 27 September, accessed 16 May 2016 at http://www.migrantsrights.org. uk/migration-pulse/2013/migration-and-integration-are-now-policy-challengestoo-far-many-local-authorit.

Vertovec, S. (2007), 'Super-diversity and its implications', Ethnic and Racial Studies, 30 (6), 1024-54.

Ware, P. (2013), 'Very Small, Very Quiet, a Whisper...' - Black and Minority 
Ethnic Groups: Voice and Influence, Birmingham: Third Sector Research Centre.

Wilkinson, M. and G. Craig (2011), 'Wilful negligence: migration policy, migrants' work and the absence of social protection in the UK', in E. Carmel, A. Cerami and T. Papadopoulos (eds), Migration and Welfare in the New Europe, Bristol: Policy Press, pp. 177-94.

Zincone, G. (ed.) (2000), Primo rapporto sull'integrazione degli immigrati in Italia, Commissione per le Politiche di Integrazione degli Immigrati, Bologna: Il Mulino.

Zincone, G. (2009), Immigrazione: segnali di integrazione. Sanità, scuola e casa, Bologna: Il Mulino.

Zincone, G. and L. Di Gregorio (2002), 'Il processo delle politiche di immigrazione in Italia: uno schema interpretativo integrato', Stato e Mercato, no. 3, 433-66. 